\title{
TRGOVINA LJUDIMA KAO NAJTEŽI OBLIK KRŠENJA LJUDSKIH PRAVA
}

\author{
$U D K: 342.43$ \\ 343.6 \\ 343.544 \\ DOI: $10.31141 /$ zrpfs.2020.57.138.1097 \\ Pregledni znanstveni rad \\ Primljeno: 15. siječnja 2020.
}

Tema ovoga rada odnosi se na trgovinu ljudima što je najteži oblik kršenja ljudskih prava. Trgovina ljudima je globalni fenomen i time su pogođene gotovo sve zemlje svijeta na ovaj ili onaj način. Posebno za organizirane kriminalne skupine trgovina ljudima ima prednost nad trgovinom drogom, jer se robu, kao ljude, može prodavati iznova i iznova. Trgovina ljudima također je isplativija od „tradicionalnog“ ropstva, jer se žrtve obično "nabavljaju” iz siromašnijih zemalja i prodaju u bogatije zemlje, gdje ih se može prodati za ogroman profit. Većina žrtava su žene i djeca, posebno djevojčice, ali tijekom posljednjih godina porastao je postupno i broj muškaraca. Trgovina radi seksualnog iskorištavanja najčešći je i najrasprostranjeniji oblik trgovine ljudima, posebno u Europi, Americi i jugoistočnoj i pacifičkoj Aziji. Udio trgovine ljudima u svrhu eksploatacije radne snage također je u porastu i postao je najzastupljeniji oblik trgovine ljudima u subsaharskoj Africi, te na Bliskom istoku. Zaštita ljudskih prava sigurno je jedan od najvažnijih aspekata razvoja. Međutim, zaštita ljudskih prava dobiva mnogo manje pozornosti od ostalih aspekata, vjerojatno dijelom zato što ih je teško izmjeriti. Ljudska prava su univerzalna jer se temelje na dostojanstvu svakog čovjeka, bez obzira na rasu, boju, spol, etničko ili socijalno podrijetlo, religiju, jezik, nacionalnost, starost, seksualnu orijentaciju, invaliditet ili na bilo koje druge karakteristike.

Ključne riječi: trgovina ljudima, kršenje ljudskih prava, seksualno iskorištavanje, kazneno pravo, kriminal, ljudska prava

\section{UVOD}

Ako se vratimo davno u prošlost, može se činiti da je trgovina ljudima bila prilično beznačajna. Međutim, trgovina robljem predstavljala je problem cijelo vrijeme. Danas u razvijenom svijetu postoji opći konsenzus da je ropstvo sramota. Ipak, danas je u svakoj zemlji svijeta još uvijek aktualna priča o trgovini robljem, što ga čini jednim od najvećih zločina u našem vremenu. Pitanje nije ograničeno samo na zemlje u razvoju, niti se njime moraju baviti samo razvijeni dijelovi svijeta. Primjerice, u Bangladešu postoji prisilna radna snaga u raznim industrijama; u Sjedinjenim Američkim Državama mnoge žene su seksualno iskorištavane; u

\footnotetext{
1 Iva Milković, sveučilišna specijalistica kriminalističkog istraživanja zaposlena u MUP-u RH.
} 
Ugandi ima vojnika djece; ljudi prodaju svoje organe u Kini; na ulicama europskih prijestolnica postoje prosjaci kojima se zapravo trguje. Nadalje, vojne baze diljem svijeta često su povezane s porastom bordela, a kada vojska odlazi, djevojke se prodaju u druga mjesta s većom potražnjom. Stoga je problem trgovine ljudima vrlo širok i dubok.

Jedan od aspekata specifičan za trgovinu ljudima jest da su granični troškovi iskorištavanja osobe vrlo niski. Kad je čovjek zarobljen, i u nekom je smislu nečije vlasništvo, može se prodati više puta. Uz to, posao koji je izvršila zarobljena osoba često se može ponavljati. Dakle, eksploatacija čovjeka ograničena je samo vremenskom dimenzijom, za razliku od klasičnog dobra koje se može prodati samo jednom. Kao što se hotelska soba može iznova i iznova iznajmljivati, tako se može i s ljudskim bićem. Činjenica da su granične cijene trgovine ljudima toliko niske, znači da su eksploatirane osobe često jeftinije od onih koje nisu iskorištavane. Tako se iskorištavači uvijek mogu natjecati u cijeni. Za potrošača kojeg zanima samo cijena dobra, lako je odabrati žrtvu trgovine ljudima. Potražnja razvijenog svijeta za jeftinom radnom snagom, jeftinim predmetima ili jeftinim seksualnim uslugama održava tržište. Zemlje s velikom spremnošću za plaćanje i s velikom populacijom favorizirane su među trgovcima ljudima jer je tako očekivana dobit veća.

\section{TRGOVINA LJUDIMA KAO NAJTEŽI OBLIK KRŠENJA LJUDSKIH PRAVA}

\subsection{Trgovanje ljudima kroz povijest}

Trgovina ljudima nije sociološka kategorija, već pravosudna kategorija koja se rodila unutar diskurzivnosti potrebe za radom nadnacionalnih granica. Sredinom devetnaestoga stoljeća povećalo se protivljenje trgovini crnačkim afričkim robovima. Pored ove hitnosti, ne više humanitarne nego ekonomske, dodana je i zabrinutost zbog trgovine bijelim ženama radi prostitucije. Iako se mogu uspostaviti odnosi između tih pojava, mora biti jasno da su to različiti događaji, jer su motivirani različitim razlozima. Priprema kategorije trgovine bijelih žena, osim što uključuje latentni rasizam, temeljila se na zabrinutosti zaštite ideala ženske čistoće (Tasioulas, 2013.).

Prostitucija je uvedena u vrijeme obilježeno eugeničkim i evolucijskim teorijama. U devetnaestom stoljeću, za orijentir u stvaranju seksualne znanosti, prostitucija je tretirana kao predmet medicinskog saznanja, shvaćena kao bolest, kao društvena devijacija. Prostitutke su izbačene iz gradova, što se smatra preprekom civilizaciji i moralu. Već tada se raspravljalo o prijelazu granice prostitucije. Moralna zabrinutost proizvedena 1904. godine, bila je u jeku rasprave o trgovini robovima u Americi i o Međunarodnom ugovoru o suzbijanju trgovine bijelog roblja (Tasioulas, 2013.). To je bio prvi međunarodni instrument koji se bavio trgovinom u svrhu seksualnog iskorištavanja. 
Na kraju 19. stoljeća prostitucija se smatrala prijetnjom za tijelo, obitelj, brak, rad i imovinu, a shvaćena je kao "bolest" i postala je meta profilakse. Prostitutke su bile progonjene budući da su smatrane preprekama civilizaciji, 'moralnoj čistoći' grada, zbog čega je trebalo kontrolirati njihovo prisustvo, a njihove kuće ukloniti u skučene prostore definirane urbanim reformama. Također, iz tog doba jest izum povezanosti između žene i bolesti. Taj se pojam koristio u vezama između bolesti i pasivnosti. Diskurzivnost koja je činila prostituciju problemom, bila je moguća samo zahvaljujući politici seksualnosti, dok je trgovina sve više bivala isprepletena s medicinskim i policijskim diskursima uloženima u odbojnost prema prostituciji. Prostitucija i trgovina ljudima u obliku u kojem se danas ponovno usvajaju, slučajni su izumi (Marcon-Venson, Pedro, 2013.).

Procjenjuje se da je 12 milijuna robova krenulo iz Afrike u Ameriku između 16. stoljeća i 1866. godine. Potrebno je zapamtiti da ti brojevi uključuju samo robove koji su bili živi nakon dolaska. Broj robova koji su umrli u tranzitu i onih ubijenih tijekom hvatanja, vjerojatno je mnogo veći, ali teško je procijeniti jer nikada nisu pravilno evidentirani (Nunn i Wantchekon, 2011.). U posljednjoj trgovini u nekim dijelovima Afrike bila je 9,3-postotna vjerojatnost da ćete tijekom svog života završiti kao rob u Americi. Broj ljudi odvedenih s afričkog kontinenta ostavio je veliku pustoš u stanovništvu prema podacima iz 1850. godine (Sleight, n.d.).

Razumijevanje tržišne snage može biti izazov, a još je teži zadatak shvatiti zašto je tržište uopće stvoreno. U slučaju afričke trgovine robovima, može se pretpostaviti da je potražnjom za radnicima pokrenuto tržište. Prve tri trgovine robovima trgovalo se ljudima da bi radili u poljoprivredi ili da bi iskorištavali prirodne resurse unutar Afrike ili u muslimanskom svijetu. Potrebni su bili radnici na plantažama, pri ronjenju bisera i u radu u rudnicima. Pored toga, robove koji su prevoženi u muslimanski svijet smatrali su luksuznim dobrima, s vjerojatnošću da će raditi na domaćem tržištu (Carozza, 2013.). Za prekoatlantsku trgovinu robovima, Europljani su započeli koloniziranje Amerike što je dovelo do potrebe iskorištavanja prirodnih resursa i poljoprivrede više nego što se moglo proizvesti samo s domaćom random snagom.

Stoga je postojala potražnja za radnom snagom koja je zahtijevala malo ljudskog kapitala i grube napore. Sjevernoameričke plantaže šećera i duhana bile su velike, a proizvodnja je bila intenzivna. Većina afričkih robova bila je tu zaposlena (Carozza, 2013.). Povjesničari su htjeli odgovoriti na pitanje zašto je Afrika bila glavni izvor te radne snage. Postoji više razloga i za zaključak da su gustoća naseljenosti i etnička frakcionalizacija djelomična objašnjenja. To bi moglo biti i zato što je Afrika imala manje dobra kojima se moglo trgovati i prevoziti na veće udaljenosti. Prirodni resursi koje su imali, poput zlata, bili su ograničeni i u količini i zemljopisno, pa je njihova specijalizacija na kraju bila prijevoz radne snage, kao robova. Također je evidentna važnost religije kada je u pitanju osjećaj zajedništva među ljudima.

Nedostatak porobljavanja u raštrkanim državama Italije i Njemačke, koje su često ratovale jedna s drugom prije 70-ih godina 19. stoljeća, dogodio se zbog zajedničke kršćanske religije na tom području. Također, u Euroaziji i muslimanskom svijetu 
postojala je jedna (islam) religija koja je prelazila etničke granice, što nije bilo slučaj s Afrikom. Pored toga, Afrika je imala nisku gustoću stanovništva, što je rezultiralo manjom ljudskom interakcijom i manjom heterogenošću društva. Kada su ekonomske sile stvorile veliku potražnju za robovskom radnom snagom, Afrika je pružila plodno tlo za porobljavanje (Wolfe, 2018.).

Povijest trgovine robovima u Africi utjecala je na društva i kasniji razvoj na kontinentu, ali prethodni su se učenjaci uglavnom usredotočili na moć kolonizacije na tom području. Nunn i Wantchekon (2011.) pružaju empirijsku procjenu utjecaja razmjene robova na gospodarski razvoj i pronalaze jasan negativan odnos između količine robova koji se izvoze iz neke zemlje, i trenutnih ekonomskih učinaka. Nunn i Wantchekon (2011.) pokazali su da se barem dio toga može pripisati učinku koje je ropstvo imalo na povjerenje među stanovnicima. Ako su nečiji preci bili pod utjecajem trgovine robljem, takvi su ljudi manje vjerovali rođacima, susjedima, koetnicima i lokalnoj upravi (Nunn, Wantchekon, 2011.).

\subsection{Trgovina ljudima kao pojava}

Nema sumnje da trgovina ljudima može sadržavati više dimenzija iskorištavanja i kršenja osnovnih ljudskih prava, gdje je primarni cilj počinitelja kaznenoga djela trgovine ljudima da novac zarađuje dugoročnim izrabljivanjem žrtava. Kako bi u tome uspio, učinit će sve da zaštiti svoje ulaganje, osiguravajući se na način da žrtva nastavlja s radom i da se žrtvu spriječi u eventualnom bijegu. Trgovci ljudima osiguravaju konstantan nadzor nad žrtvama. Slaganje žrtve na eksploataciju nije važno u slučaju kad god se radi o nekom obliku prinude. U dosta slučajeva stupanj psihičkih i fizičkih povreda toliko je ozbiljan i trajan da nije moguće fizičko i mentalno zdravlje žrtve vratiti u prijašnje normalno stanje (UNODOC, 2010.).

Trgovina ljudima globalan je fenomen i time su na ovaj ili onaj način pogođene gotovo sve zemlje svijeta. Posebno za organizirane kriminalne skupine trgovina ljudima ima prednost nad trgovinom drogom, jer se roba, kao ljudi, može prodavati iznova i iznova. Trgovina ljudima također je isplativija od „tradicionalnog“" ropstva, jer se žrtve obično nabavljaju iz siromašnijih zemalja i prodaju u bogatije zemlje, gdje ih se može prodati za ogroman profit. Većinu žrtava čine žene i djeca, posebno djevojčice, ali tijekom posljednjih godina broj muškaraca je također postupno porastao. Trgovina radi seksualnog iskorištavanja najčešći je i najrasprostranjeniji oblik trgovine ljudima, posebno u Europi, Americi i jugoistočnoj i pacifičkoj Aziji. Udio trgovine ljudima u svrhu eksploatacije radne snage također je u porastu i postao je najzastupljeniji oblik trgovine ljudima u subsaharskoj Africi i na Bliskom istoku. Svake godine identificira se sve više žrtava trgovine ljudima zbog činjenice da su zemlje bolje pripremljene i sposobnije su prikupljati podatke i izvještavati o otkrivenim slučajevima trgovine ljudima. Iako je UNODC (Ured Ujedinjenih naroda za droge i kriminal) ocijenio da porast otkrivenih slučajeva također može ukazivati na to kako je trgovina ljudima u posljednjih nekoliko godina postala još raširenija. 
Porast trgovine ljudima u dvadeset prvom stoljeću može se promatrati kao rezultat porasta ekonomskih i demografskih nejednakosti, sve većeg pritiska stanovništva, globalizacije koja prelazi granice i povećanja količine sukoba. Globalizacija je posebno dovela do povećanja trgovine ljudima kao transnacionalnog organiziranog kriminala zbog slabosti nacionalnih država, granične kontrole i promjena u međunarodnoj ekonomiji. Nove tehnologije i posebno platforme društvenih medija otvorile su širi spektar mogućnosti i za trgovce ljudima. Organizirane kriminalne skupine u Indiji i Rusiji u stanju su kupiti i prodati žene jednostavnim klikom miša. Pitanje trgovine ljudima dodatno je pogoršano raširenom korupcijom u brojnim zemljama i kulturnim čimbenicima u mnogim regijama, poput slabog statusa žena i djece i tradicije koju potomstvo mora osigurati obitelji pod svaku cijenu. Trgovina ljudima nema samo štetne posljedice za svoje žrtve. Također utječe na društva na brojne načine jer slabi vladavinu zakona i poštovanje prava pojedinca. Uz to, trgovina ljudima utječe na ekonomiju jer eksploatacija radne snage naknadno smanjuje plaće legitimnih radnika, a žrtve trgovine ljudima ne doprinose ekonomiji zemlje. Važno je priznati da je trgovina ljudima prije svega društveni problem i posljedica niza socijalnih i ekonomskih problema. Trgovina ljudima ne može se riješiti samo zakonodavnim mjerama, ali pravni odgovori imaju veliku važnost za žrtve i dugoročno doprinose borbi protiv ovog fenomena. S pravnog stajališta, trgovina ljudima promatra se kao fenomen na raskrižju ljudskih prava, kriminala i migracija. Pored toga što je kazneno djelo, trgovina ljudima smatra se grubim kršenjem ljudskih prava. Povreda je dostojanstva i integriteta ljudskog bića. Posebno Konvencija Vijeća Europe o suzbijanju trgovanja ljudima ističe ovaj aspekt ljudskih prava.

Krijumčarenje migranata vrlo je usko povezano s trgovinom ljudima i često se ta pitanja rješavaju istovremeno. U mnogim situacijama kada postoji potražnja za uslugama krijumčarenja ilegalnim trgovcima, trgovci ljudima također pronalaze udio u svom poslu. Neki će možda započeti svoje putovanje kao klijenti krijumčara migranata, ali na kraju ih iskorištavaju trgovci ljudima, na primjer, jer su prisiljeni vratiti troškove putovanja radom ili prostitucijom. Ipak, krijumčarenje migranata i trgovina ljudima trebaju se smatrati kao dva odvojena pitanja. Istovremeno s usvajanjem Protokola o trgovini ljudima, usvojen je poseban Protokol protiv krijumčarenja migranata kopnom, morem i zrakom koji signalizira razdvajanje ova dva pitanja. Razumijevanje i definiranje trgovine ljudima predstavljalo je problem u kasnom devetnaestom stoljeću. Trgovanje ljudima prvi put je obrađeno u Međunarodnom sporazumu o suzbijanju trgovine "bijelih robova" 1904. Trgovina bijelim robljem odnosila se isključivo na prostituciju bijelih žena i djevojčica. Konvencija o suzbijanju trgovanja ljudima i iskorištavanju tuđe prostitucije 1949. godine kombinirala je sve svoje prethodne ugovore u jedan što će ostati centralni ugovor koji se bavi trgovinom ljudima do 2000. godine. Definicija Konvencije iz 1949. o trgovini ljudima odnosila se samo na iskorištavanje prostitucijom, a trgovanje ljudima bilo je izvan okvira konvencije. Konvencija je, međutim, imala određeni potencijal jer je prepoznala da muškarci i dječaci mogu biti podložni prostituciji, te je primijenjena kako na unutarnju tako i na međunarodnu trgovinu 
ljudima. Konvencija iz 1949. još uvijek je široko kritizirana zbog nekoliko propusta i nije dostigla osobito uspješan ratifikacijski status. Očito je postojala potreba za sveobuhvatnim ugovorom o pitanju i nastanku transnacionalnog organiziranog kriminala i krijumčarenja migranata na prijelazu stoljeća uslijed širenja fenomena trgovine ljudima (Gallagher, 2018.).

Organizirane kriminalne skupine nikako nisu jedine koje se bave trgovinom ljudima. U svrhu ove teze, organizirane kriminalne skupine pružaju zanimljivu skupinu, jer one najvjerojatnije imaju dobro financirane, organizirane i strukturirane poslovne modele i potencijalno bi mogli izvesti široke ili sustavne napade na civilno stanovništvo. To, međutim, dovodi do većeg pitanja odnosa transnacionalnog organiziranog kriminala i međunarodnog kaznenog prava, koje nije moguće pregledati u okviru ove teze. Međunarodno kazneno pravo trebalo bi se koristiti u borbi protiv transnacionalnog organiziranog kriminala, jer međunarodne konvencije koje se bave tim pitanjem očito nisu bile dovoljne.

Raznolikost oblika u kojima se može dogoditi trgovina ljudima predstavlja niz problema. Možda se ne smatra da se neki oblici uzdižu do iste razine ozbiljnosti kao drugi. Stoga se postavlja pitanje gdje povući crtu i koje prakse spadaju u zakonsku definiciju trgovine ljudima. Prevelika generacija termina trgovanja ljudima lako može dovesti do prekomjernog pojednostavljenja problema i rezultirati situacijom u kojoj se zanemaruju mnoge eksploatacijske prakse. S druge strane, isključivanje određenih oblika trgovine može jednako tako izazvati zbrku. Na primjer, nisu svi oblici ili slučajevi rada pod eksploatacijskim uvjetima trgovina ljudima. Mnogo je različitih razloga zbog kojih ljudi završe raditi u užasnim uvjetima. U pozadini bi moglo postojati duboko ukorijenjeno siromaštvo i ranjivost, ali rad u nepovoljnim uvjetima ne predstavlja trgovinu ljudima ako se radi dobrovoljno, a ne pod prisilom. Nadalje, svaki pojedinac je različit i iskustva o tome što čini prisilu mogu biti različita. U svakom slučaju, koncept prisilnog rada pokriva širi raspon situacija i ima niži prag od trgovine ljudima (Ezeilo, 2018.).

\subsection{Kršenje ljudskih prava}

Ljudska prava opisuju moralne norme ili moralne standarde koji se shvaćaju kao neotuđiva temeljna prava svakog ljudskog bića. Ljudska prava obuhvaćaju širok raspon prava, uključujući, ali ne ograničavajući se na pravo na pošteno suđenje, zaštitu tjelesnog integriteta, zaštitu od porobljavanja, pravo na slobodu govora i pravo na obrazovanje.

Zaštita ljudskih prava sigurno je jedan od najvažnijih aspekata razvoja. Međutim, zaštita ljudskih prava dobiva mnogo manje pozornosti od ostalih aspekata, vjerojatno dijelom zato što ih je teško izmjeriti. Ako je netko zainteresiran za empirijsko proučavanje zaštite ljudskih prava, nije dovoljno promatrati zemlje koje ratificiraju ugovore o ljudskim pravima; umjesto toga, kvantitativno istraživanje ljudskih prava ima za cilj utvrditi jesu li određena ljudska prava zaštićena u praksi ili ne (Roser, 2020.). 
Znanstvenici u području međunarodnih odnosa usredotočeni su na transnacionalne čimbenike kako bi objasnili razlike u praksi ljudskih prava u različitim zemljama. Amnesty International i Human Rights Watch istaknuti su primjeri utjecajnih nevladinih organizacija koje sklapaju saveze s domaćim skupinama civilnog društva u mnogim zemljama Azije, Latinske Amerike i Afrike. Ove transnacionalnodomaće alijanse važne su za stalni pritisak na nacionalne vlade da poštuju različite norme o ljudskim pravima, posebno na područjima gdje su etnički sukobi, građanski ratovi i drugi oblici političkog nasilja i dalje endemični. Osim toga, Ured visokog povjerenika UN-a i njegovi odbori neovisnih stručnjaka strogo prate poštovanje država temeljem međunarodnih ugovora o ljudskim pravima. Ovi se ugovori odnose na nekoliko područja zabrinutosti, uključujući sljedeće: uklanjanje svih oblika rasne diskriminacije, građanska i politička prava, ekonomska, socijalna i kulturna prava, prava djeteta $i$, između ostalog, sprečavanje diskriminacije žena. Ono što je najvažnije, Univerzalna deklaracija o ljudskim pravima (UDHR), stvorena kao odgovor na stravična ubojstva holokausta tijekom Drugog svjetskog rata, predstavlja najraniju svjetsku artikulaciju svih privilegija na koja sva ljudska bića imaju pravo, bez obzira na rasu, spol, vjeru ili kulturološku pozadinu.

Sve u svemu, sve ove međunarodne i regionalne organizacije i međunarodni pravni instrumenti čine ono što danas nazivamo globalnim režimom ljudskih prava. Glavni stav, često nazvan liberalnim stavom, koji koriste mnogi znanstvenici za međunarodne odnose, tvrdi da je takav režim važan jer vrši pritisak na države u kojima se provodi nasilje i nedržavne aktere da se pridržavaju normi o ljudskim pravima (Regilme, 2016.).

Ljudska su prava univerzalna jer se temelje na dostojanstvu svakog čovjeka, bez obzira na rasu, boju, spol, etničko ili socijalno podrijetlo, religiju, jezik, nacionalnost, starost, seksualnu orijentaciju, invaliditet ili bilo koje druge karakteristike. Budući da ih prihvaćaju sve države i narodi, ljudska prava se primjenjuju jednako i neselektivno prema svakoj osobi i za sve posvuda (UNHR, 2016.).

Univerzalnost ljudskih prava ponekad se dovodi u pitanje na osnovi toga što su ona zapadnjački pojam, dio neokolonijalnog stava koji se propagira širom svijeta. Studija koju je 1968. objavila Organizacija ujedinjenih naroda za obrazovanje, znanost i kulturu (UNESCO) jasno je pokazala da duboke težnje u temelju ljudskih prava odgovaraju pojmovima - konceptima pravde, integriteta i dostojanstva pojedinca, slobode od ugnjetavanja i progona i sudjelovanje pojedinaca $u$ kolektivnim nastojanjima - koji se susreću u svim civilizacijama i razdobljima. Ipak, tvrdnje da ljudska prava nisu univerzalna i dalje se pojavljuju u različitim kontekstima. Na primjer, države su često dovodile u pitanje univerzalnost ljudskih prava opravdavajući kršenja ljudskih prava žena u ime kulture. Ove se prakse često temelje na štetnim stereotipima o ulozi žene u društvu, a obveza uklanjanja takvih stereotipa i predrasuda jasna je međunarodnim zakonom o ljudskim pravima. Perspektiva ljudskih prava prepoznaje kako se kultura s vremenom mijenja, a također ispituje utječu li žene na procese donošenja odluka koje definiraju kulturu svake zajednice. Univerzalnost ljudskih prava potvrđuje činjenicu da je većina nacija, 
koje pokrivaju čitav spektar kulturnih, religijskih i političkih tradicija, usvojila i ratificirala glavne međunarodne instrumente ljudskih prava (UNHR, 2016: 21-22).

Neka od najgorih kršenja ljudskih prava rezultat su diskriminacije prema određenim skupinama. Pravo na jednakost i zabranu diskriminacije izričito je utvrđeno međunarodnim i regionalnim ugovorima o ljudskim pravima, stoga su oni osnova za zaštitu svih ljudskih prava. Pravo na jednakost obvezuje države da osiguraju poštovanje ljudskih prava bez diskriminacije po bilo kojoj osnovi, uključujući spol, rasu, boju, jezik, religiju, političko ili drugo mišljenje, nacionalno, etničko ili socijalno podrijetlo, pripadnost nacionalnoj manjini, imovini, rođenju, starosti, invaliditetu, seksualnoj orijentaciji i socijalnom ili drugom statusu. Nadalje, važno je napomenuti da diskriminaciju ne tvori samo neopravdano „razlikovanje, isključenje ili ograničenje“, već i neopravdana „preferencija“ u odnosu na određene skupine. Borba protiv diskriminacije i danas ostaje borba za mnoge ljude širom svijeta (UNHR, 2016: 32).

Čovjekove slobode predstavljaju univerzalne vrijednosti te moraju biti u centru zaštite ljudskih prava, kako u drugim zemljama, tako i u Republici Hrvatskoj. U Republici Hrvatskoj garantiraju se i osiguravaju ravnopravnost, slobode i prava čovjeka, zasnovani na najvišim vrijednostima ustavnog poretka sloboda, jednakosti, nacionalne ravnopravnosti i na ravnopravnost spolova, mirotvorstva, socijalne pravde, poštovanja prava čovjeka, nepovredivosti vlasništva, očuvanja prirode i čovjekova okoliša, vladavine prava i demokratskog višestranačkog sustava (Ustav članak 7.). Uslijed toga, opću sliku zaštite ljudskih prava definira načelo ravnopravnosti člankom 14. Ustava kojim je uređeno da „svatko u Republici Hrvatskoj ima prava i slobode neovisno o njegovoj rasi, boji kože, spolu, jeziku, vjeri, političkom ili drugom uvjerenju, nacionalnom ili socijalnom podrijetlu, imovini, rođenju, naobrazbi, društvenom položaju ili drugim osobinama“" (Ured za ljudska prava i prava nacionalnih manjina, 2020.).

\subsection{Međunarodni instrumenti ljudskih prava}

Postoji devet osnovnih međunarodnih ugovora o ljudskim pravima. Ugovori Ujedinjenih naroda o ljudskim pravima temelj su u međunarodnom sustavu za promicanje i zaštitu ljudskih prava. Svaki od ovih ugovora osnovao je stručni odbor (ugovorna tijela) koji bi nadgledao provedbu odredaba ugovora. Neki se ugovori nadopunjuju neobaveznim protokolima koji se bave određenim problemima. Izvorni protokol o ugovoru instrument je koji uspostavlja dodatna prava i obveze prema ugovoru. U nastavku navodimo devet osnovnih međunarodnih ugovora o ljudskim pravima (WWDA, 2020.):

\section{Međunarodna konvencija o uklanjanju svih oblika rasne diskriminacije (ICERD)}

Međunarodna konvencija o uklanjanju svih oblika rasne diskriminacije (ICERD) jest konvencija Ujedinjenih naroda koja je usvojena i otvorena za potpisivanje i 
ratifikaciju Rezolucijom 2106 (XX) Generalne skupštine Ujedinjenih naroda 21. prosinca 1965. i koja je stupila na snagu 4. siječnja 1969. godine.

\section{Međunarodni pakt o građanskim i političkim pravima (ICCPR)}

Međunarodni pakt o građanskim i političkim pravima jest ugovor Ujedinjenih naroda utemeljen na Univerzalnoj deklaraciji o ljudskim pravima, stvorenoj 1966. te je isti stupio na snagu 23. ožujka 1976. godine. Pakt sadrži dva neobavezna protokola. Prvi neobvezni protokol stvara pojedinačni mehanizam za podnošenje pritužbi putem kojeg pojedinci u državama članicama mogu podnijeti žalbe, poznate kao komunikacije, na razmatranje u Odboru za ljudska prava. Njegove odluke u okviru prvog neobaveznog protokola stvorile su najsloženije sudske prakse u međunarodnom sustavu prava UN-a o ljudskim pravima. Drugi neobavezni protokol ukida smrtnu kaznu.

\section{Međunarodni pakt o ekonomskim, socijalnim i kulturnim pravima (ICESCR)}

Međunarodni sporazum o ekonomskim, socijalnim i kulturnim pravima jest multilateralni ugovor koji je Opća skupština Ujedinjenih naroda usvojila 16. prosinca 1966., a na snazi je od 3. siječnja 1976. godine. Obvezuje države stranke da rade na davanju ekonomskih, socijalnih i kulturoloških prava pojedincima.

\section{Konvencija o uklanjanju svih oblika diskriminacije žena (CEDAW)}

Konvencija o uklanjanju svih oblika diskriminacije žena međunarodna je konvencija koju je 1979. godine usvojila Opća skupština Ujedinjenih naroda. Opisana međunarodnim nacrtom prava za žene, stupila je na snagu 3. rujna 1981. godine. Konvencija u svom 1. članku definira diskriminaciju žena sljedećim izrazima: „Za svrhe ove konvencije, izraz “diskriminacija žena” označava svaku razliku, isključenje ili ograničenje u pogledu spola, što ima za posljedicu ili cilj da ugrozi ili onemogući priznanje, ostvarenje ili vršenje od strane žena, ljudskih prava i osnovnih sloboda na političkom, ekonomskom, društvenom, kulturnom, građanskom ili drugom polju, bez obzira na njihovo bračno stanje, na osnovi ravnopravnosti muškaraca i žena" (CEDAW, 1979.). Također, uspostavlja dnevni plan djelovanja za zaustavljanje diskriminacije na temelju spola: Države koje ratificiraju Konvenciju dužne su u svoje domaće zakonodavstvo unijeti ravnopravnost muškaraca i žena, ukinuti sve diskriminatorne odredbe u svojim zakonima i donijeti nove odredbe kojima će se zaštititi od diskriminacija žena. Također moraju osnovati sudove i javne institucije koje će zajamčiti ženama djelotvornu zaštitu od diskriminacije, te poduzeti korake za uklanjanje svih oblika diskriminacije koje pojedinci, organizacije i poduzeća provode protiv žena. Opća skupština Ujedinjenih naroda je 1999. godine usvojila neobavezni protokol CEDAW. Protokol uključuje postupak putem kojeg pojedine žene ili grupe mogu neposredno osuditi nacionalna kršenja CEDAW-a pred komitetom stručnjaka CEDAW-a. 


\section{Konvencija protiv mučenja i drugog okrutnog, nečovječnog ili ponižavajućeg} postupanja ili kažnjavanja (CAT)

Konvencija Ujedinjenih naroda protiv mučenja i drugog okrutnog, nečovječnog ili ponižavajućeg postupanja ili kažnjavanja međunarodni je instrument ljudskih prava, pod nadležnošću Ujedinjenih naroda, čiji je cilj sprečavanje mučenja širom svijeta. Konvencija zahtijeva od država da poduzmu učinkovite mjere za sprečavanje mučenja unutar svojih granica i zabranjuje državama povratak ljudi u njihovu matičnu zemlju ako postoji razlog da vjeruju da će biti mučeni. Tekst Konvencije Generalna skupština Ujedinjenih naroda usvojila je 10. prosinca 1984. godine, a nakon što ju je 20 zemalja ratificiralo, stupila je na snagu 26. lipnja 1987. godine. Izborni protokol uz Konvenciju protiv mučenja i drugih okrutnih, neljudskih ili ponižavajućih postupanja ili kažnjavanja, Opća je skupština usvojila 18. prosinca 2002., a na snazi je od 22. lipnja 2006. godine. Konvencija predviđa uspostavu sustava redovnih posjeta neovisnih međunarodnih i nacionalnih tijela mjestima gdje su ljudi lišeni slobode, kako bi se spriječilo mučenje i drugo okrutno, nečovječno ili ponižavajuće postupanje ili kažnjavanje.

\section{Konvencija o pravima djeteta $(C R C)$}

Konvencija Ujedinjenih naroda o pravima djeteta, često nazivana „CRC“, međunarodna je konvencija koja određuje građanska, politička, ekonomska, socijalna i kulturna prava djece. Generalna skupština Ujedinjenih naroda složila se usvojiti Konvenciju u međunarodno pravo 20. studenoga 1989., a stupila je na snagu 2. rujna 1990. godine, nakon što ju je ratificirao potrebni broj država. Konvencija uglavnom definira dijete kao i svaku osobu mlađu od 18 godina, osim ako zakoni neke zemlje drugačije tretiraju punoljetnost. Konvencija ima dva neobavezna protokola, koja je Opća skupština usvojila u svibnju 2000. godine, a primjenjiva su na one države koje su ih potpisale i ratificirale.

\section{Međunarodna konvencija o zaštiti prava svih radnika migranata i članova} njihovih obitelji (ICRMW)

Međunarodna konvencija o zaštiti prava svih radnika migranata i članova njihovih obitelji stupila je na snagu 1. srpnja 2003. godine. Konvencija predstavlja sveobuhvatan međunarodni ugovor koji se odnosi na zaštitu prava radnika migranata. Naglašava povezanost migracija i ljudskih prava. Njegovo postojanje postavlja moralni standard i služi kao vodič i poticaj za promicanje prava migranata u svakoj zemlji.

\section{Međunarodna konvencija za zaštitu svih osoba od prisilnog nestanka (CED)}

Međunarodna konvencija za zaštitu svih osoba od prisilnog nestanka međunarodni je instrument Ujedinjenih naroda za ljudska prava namijenjen sprečavanju prisilnog nestanka. Tekst je usvojila Opća skupština Ujedinjenih naroda 20. prosinca 2006., a 
otvoren je za potpisivanje 6. veljače 2007. godine. Stupio je na snagu 23. prosinca 2010. godine.

\section{Konvencija o pravima osoba s invaliditetom (CRPD)}

Konvencija o pravima osoba s invaliditetom i njen neobavezni protokol usvojeni su 13. prosinca 2006. godine u sjedištu Ujedinjenih naroda u New Yorku, a otvorena je za potpisivanje 30. ožujka 2007. godine. Stupila je na snagu 3. svibnja 2008. godine. Konvencija je zamišljena kao instrument ljudskih prava s eksplicitnom dimenzijom društvenog razvoja. Ona usvaja široku kategorizaciju osoba s invaliditetom i potvrđuje da sve osobe sa svim vrstama invaliditeta moraju uživati sva ljudska prava i temeljne slobode. Pojašnjava i kvalificira kako se sve kategorije prava primjenjuju na osobe s invaliditetom te identificira područja u kojima se osobe s invaliditetom moraju prilagoditi kako bi učinkovito ostvarivali svoja prava i područja na kojima su njihova prava povrijeđena i gdje se zaštita prava mora pojačati. Izborni protokol omogućuje UN-ovom Odboru za prava osoba s invaliditetom primanje i razmatranje komunikacija od ili u ime pojedinaca ili grupa pojedinaca koji podliježu njegovoj nadležnosti i koji tvrde da su žrtve kršenja odredaba te Konvencije.

\subsection{Zakonodavni okvir u Republici Hrvatskoj}

Izgradnju pravnog sustava suzbijanja trgovanja ljudima Republika Hrvatska je započela ratifikacijom Konvencije Ujedinjenih naroda protiv transnacionalnog organiziranog kriminala iz 2000., Protokol za sprečavanje, suzbijanje i kažnjavanje trgovanja ljudi, posebice žena i djece iz 2000. te Protokol protiv trgovanja migranata kopnom, morem i zrakom, kojima se dopunjuje Konvencija Ujedinjenih naroda protiv transnacionalnoga organiziranog kriminaliteta. Daljnji važan korak ostvaren je ratifikacijom Konvencije Vijeća Europe o suzbijanju trgovanja ljudima iz 2005., kao i harmoniziranjem s Direktivom 2011/36/EU o prevenciji i suzbijanju trgovanja ljudima i zaštiti žrtava u procesu pristupanja Republike Hrvatske Europskoj uniji (Ofak i Munivrana-Vajda, 2018.).

Sukladno Ministarstvu unutarnjih poslova Republike Hrvatske (2020.), ključni preduvjet za učinkovitu borbu protiv trgovine ljudima predstavlja kreiranje odgovarajućeg zakonodavnog okvira za progon počinitelja kaznenog djela trgovanja ljudima kao i za pružanje pomoći i zaštite žrtvama.

U Republici Hrvatskoj kreirani su adekvatni zakonski okviri koji se bave pitanjem trgovanja ljudima (MUP, 2020.):

- Kazneni zakon (NN 110/97, 27/98, 129/00, 51/01 i 105/04, 84/05, 71/06 i 152/08, 125/11, 144/12)

- Zakon o kaznenom postupku (NN 110/97, 27/98, 58/99, 112/99, 62/03, 58/02, $143 / 02,115 / 06,152 / 08)$

- Zakon o USKOK-u (NN 88/01, 12/02, 33/05, 48/05, 76/07) 
- Zakon o sudovima za mladež (NN 111/97, 27/98, 12/02)

- Zakon o odgovornosti pravnih osoba za kaznena djela (NN 151/03)

- Zakon o zaštiti svjedoka (NN 163/03)

- Zakon o strancima (NN 79/07, 36/09)

- Zakon o sprečavanju pranja novca (NN 69/97, 106/97, 114/01, 117/03, 142/03, 189/03)

- Zakon o međunarodnoj pravnoj pomoći u kaznenim stvarima (NN 178/04)

- Zakon o azilu (NN 79/07, 88/10)

- Zakon o novčanoj naknadi žrtvama kaznenih djela (NN 80/08) - stupa na snagu danom ulaska Republike Hrvatske u EU.

Trgovanje ljudima predstavlja kazneno djelo uglavnom s elementom međunarodnog karaktera, a Republika Hrvatska je, pored drugih susjednih zemalja, na važnom tranzitnom pravcu, pa je zadnjih godina povećan broj identificiranih žrtava trgovanja ljudima. Sukladno podacima Ministarstava unutarnjih poslova, najčešći pravci kretanja trgovaca ljudima su sljedeći međunarodni pravci: Ukrajina - Srbija - Bosna i Hercegovina - Hrvatska; Moldavija - Srbija - Bosna i Hercegovina Hrvatska; Srbija - Hrvatska; Bosna i Hercegovina - Hrvatska; Hrvatska - Slovenija - Austrija - Švicarska; Hrvatska - Slovenija - Italija - Francuska - Španjolska (Munivrana-Vajda, Dragičević-Prtenjača, Maršavelski, 2016.).

Kada se govori o segmentu nezakonitih migracija, iste su regulirane, Zakonom o strancima, s nekoliko pravilnika, Protokolom o postupanju prema djeci bez pratnje, standardnim operativnim postupcima koji se odnose na tražitelje azila i sporazumima o readmisiji. Tijekom 2018. godine izmijenjen je i dopunjen Zakon o strancima (NN 130/11., 74/13., 69/17. i 46/18.) i na snagu je stupio Pravilnik o postupanju s državljanima trećih zemalja (NN 68/2018.) kao i Pravilnik o besplatnoj pravnoj pomoći u procesu povratka (NN 57/18.) (European Commission, 2018).

Među ostalim izmjenama Zakona o strancima, propisana je nova definicija rizika od izbjegavanja. Zakon o izmjenama i dopunama Zakona o strancima (NN 46/18. 27) izmijenjen je tako da se proširio popis okolnosti koje mogu ukazivati na postojanje rizika od izbjegavanja.

Popis okolnosti proširen je, među ostalim, na (European Commission, 2018.):

- državljanin treće zemlje koji nema ispravu o identitetu ili putnu ispravu;

- državljanin treće zemlje koji nema osiguran smještaj;

- državljanin treće zemlje koji nema prijavljen boravak;

- državljanin treće zemlje izjavio je da neće izvršavati ili da će onemogućavati izvršenje mjera za osiguranje povratka.

Pravilnik o besplatnoj pravnoj pomoći u postupku povratka propisuje dva obrasca (obavijest o besplatnoj pravnoj pomoći i izjavu o imovinskom stanju), koji su sada prevedeni na jezik koji stranac razumije. Isto tako, sukladno Pravilniku implementiran je besplatan pravni savjet za svakoga kome je donesena odluka 
o povratku. Na osnovi Pravilnika, Ministarstvo unutarnjih poslova objavilo je Javni poziv za prijavitelje iz područja upravnih sudova u Zagrebu, Splitu, Rijeci i Osijeku za pružanje pravne pomoći državljanima trećih zemalja u postupku povrata. Pravilnik o postupanju prema državljanima trećih zemalja propisuje izgled i sadržaj obrasca odbijanja ulaska u RH, zapovijedi o vraćanju, rješenja o povratku, rješenja o protjerivanju, upozorenja o odlasku u državu članicu Europskog gospodarskog prostora, potvrde o kratkotrajnom boravku, obrasca europske putne isprave za vraćanje državljana trećih zemalja koji nezakonito borave i drugih relevantnih dokumenata (European Commission, 2018.).

\section{ZAKLJUČAK}

Trgovina ljudima nije samo širok, već je i dubok problem. Za pojedince angažirane u ovom obliku ropstva, posljedice su ogromne. Čak i ako budu oslobođeni, fizičko i psihičko zlostavljanje koje su doživjeli vjerojatno će ih pratiti cijeli život. Zbog mnogih oblika trgovine ljudima, teško je dati ujednačen opis načina na koji će trgovina utjecati na nečiji život. Također je uobičajeno da su žrtve psihološki zlostavljane, prijete kako će ozlijediti sebe ili obitelj kod kuće, što može biti okrutno gotovo kao i fizičko zlostavljanje.

Jasno je da je trgovina ljudima širok i dubok problem u društvu, što je krajnje potrebno shvatiti ozbiljno. Budući da se može općenito predvidjeti odakle dolaze žrtve trgovanja ljudima, može se koristiti znanje o tržišnim mehanizmima u nastojanju zaustavljanja problema. Međutim, nedostaju istraživanja na polju trgovine ljudima, što ovo čini teškim zadatkom. Potrebni su i bolji podaci i veći interes među znanstvenicima, iako ovo drugo najvjerojatnije ovisi o prvom.

Kada je riječ o sprečavanju trgovine ljudima, moramo prije svega obratiti pažnju na uzroke koji dovode do situacije trgovine ljudima. Siromaštvo, nezaposlenost ili nasilje u obitelji kao uzroci trgovine ljudima potječu iz različitih društvenih sfera, što odražava prirodu ekonomskih, političkih, obiteljskih i drugih odnosa u zajednici.

Otkrivanje uzroka prvi je i bitan korak u stvaranju funkcionalnih i učinkovitih reakcija kako na samo postojanje uzroka, tako i na obnavljanje njihovih posljedica. $\mathrm{U}$ tom pogledu postoje dva glavna smjera s kojima se suočavaju programi prevencije: jedan se odnosi na smanjenje ili eventualno uklanjanje uzroka, a drugi se odnosi na rehabilitaciju pojedinačnih, grupnih ili općih društvenih posljedica koje su nastupile kao posljedica trgovine ljudima. Međutim, praksa pokazuje da je većina preventivnih programa usmjerena na uklanjanje stvarnih ili očekivanih posljedica, kako kroz rad sa žrtvama trgovine ljudima, tako i kroz širu populaciju. 


\section{LITERATURA}

1. Carozza, P. G. (2013.). Human Rights, Human Dignity, and Human Experience. Understanding Human Dignity. doi: 10.5871/bacad/9780197265642.003.0036

2. CEDAW (1979.). Konvencija o ukidanju svih oblika diskriminacije žena. Dostupno na: http://www.unmikonline.org/regulations/unmikgazette/05bosniak/ BConEliminationDiscriminationWomen.pdf (pristupljeno: 5. II. 2020.)

3. European Commission (2018.). GODIŠNJE IZVJEŠĆE ZA 2018. GODINU O MIGRACIJAMA I AZILU U HRVATSKOJ. Nacionalno izvješće (2. dio)

4. Ezeilo, J.N. (2018.). Trafficking in human beings in the African context, in Piotrowicz, Ryszard; Rijken, Conny; Uhl, Baerbel Heide (ed.): Routledge Handbook of Human Trafficking, Routledge; 52-67.

5. Gallagher, Anne T. (2018.). Trafficking in transnational criminal law, in Piotrowicz, Ryszard; Rijken, Conny; Uhl, Baerbel Heide (ed.): Routledge Handbook of Human Trafficking, Routledge.

6. HRVATSKOJ - PRAVNI STANDARD KAO FIKCIJA ILI STVARNOST. Zbornik radova Pravnog fakulteta u Splitu, god. 53, 4/2016., str. 991-1009.

7. Maiese, M. (2003.). Human Rights Violations. Beyond Intractability. Eds. Guy Burgess and Heidi Burgess. Conflict Information Consortium, University of Colorado, Boulder.

8. Marcon-Venson, A., Pedro, J.M. (2013.). Human trafficking: a historical approach to the concept. Revista Brasileira de História. São Paulo, v. 33, nº 65, p. 59-81

9. Ministarstvo unutarnjih poslova Republike Hrvatske - MUP (2020.). Kako zakon može zaštititi žrtve trgovanja ljudima? Dostupno na: https://mup.gov.hr/istaknuteteme/nacionalni-programi-i-projekti/nacionalni-programi-237/suzbijanje-trgovanjaljudima/kako-zakon-moze-zastititi-zrtve-trgovanja-ljudima/282030 (pristupljeno: 5. II. 2020.)

10. Munivrana-Vajda, M., Dragičević-Prtenjača, M., Maršavelski, A. (2016.). NEKAŽNJAVANJE ŽRTAVA TRGOVANJA LJUDIMA U HRVATSKOJ

11. Nunn, N. \& L. Wantchekon (2011). ,The Slave Trade and the Origins of Mistrust in Africa“. American Economic Review No. 101.

12. Ofak, V. i Munivrana-Vajda, M. (2018.). PREPORUKE ZA POBOLJŠANJE HRVATSKOG PRAVNOG OKVIRA I MJERA ZA SUZBIJANJE I PREVENCIJU TRGOVANJA LJUDIMA. Izvorni znanstveni rad

13. Regilme, S. S. (2016.). Human Rights Violations and Protections. The SAGE Encyclopedia of War: Social Science Perspectives. doi: 10.4135/9781483359878. n310

14. Roser, M. (2020.). Human Rights. Dostupno na: https://ourworldindata.org/humanrights (pristupljeno: 5. II. 2020.)

15. Sleight, R. G. (n.d.). Fluorescent Glycerolipid Probes: Synthesis and Use for Examining Intracellular Lipid Traficking. Biomembrane Protocols, 143-160. doi: $10.1385 / 0-89603-250-7: 143$ 
16. Tasioulas, J. (2013.). Human Dignity and the Foundations of Human Rights. Understanding Human Dignity. doi: 10.5871/bacad/9780197265642.003.0016

17. UNHR (2016.). Human Rights. Handbook for Parliamentarians $\mathrm{N}^{\circ} 26$. Dostupno na: https://www.ohchr.org/Documents/Publications/HandbookParliamentarians.pdf (pristupljeno: 5. II. 2020.)

18. UNODOC (2010.). Trgovina ljudima i krijumčarenje migranata. Smjernice za međunarodnu suradnju, Ured Ujedinjenih naroda za drogu i kriminal, Beograd.

19. Ured za ljudska prava i prava nacionalnih manjina (2020.). Zaštita i promicanje ljudskih prava. Dostupno na:https://pravamanjina.gov.hr/zastita-i-promicanjeljudskih-prava/597 (pristupljeno: 27. I. 2020.)

20. Wolfe, B. (2018.). The Changing Landscape of Transgender Sex Work, Pimping, and Traficking in Brazil. Transgender Sex Work and Society, 264-286.

21. WWDA (2020.). Core International Human Rights Instruments (Treaties) and The Treaty Bodies. Dostupno na: http://wwda.org.au/issues/unhrt/hrcore1/ (pristupljeno:

5. II. 2020.)

\section{HUMAN TRAFFICKING, THE HARDEST FORM OF HUMAN RIGHTS VIOLATION}

The topic of this paper concerns trafficking in human beings as the most serious form of human rights violation. Trafficking in human beings is a global phenomenon and almost all countries in the world are affected in one way or another. Especially for organized crime groups, trafficking in human beings takes precedence over drug trafficking, because goods, as humans, can be sold over and over again. Trafficking in human beings is also more cost-effective than "traditional" slavery, as victims are usually sourced from poorer countries and sold to richer countries where they can be sold for huge profits. Most of the victims are women and children, especially girls, but in recent years the number of men has gradually increased. Trafficking for sexual exploitation is the most common and widespread form of trafficking, especially in Europe, America, and Southeast and Pacific Asia. The share of human trafficking for labor exploitation is also on the rise and has become the most prevalent form of trafficking in sub-Saharan Africa and the Middle East. Protecting human rights is certainly one of the most important aspects of development. However, human rights protection receives much less attention than other aspects, probably partly because they are difficult to measure. Human rights are universal because they are based on the dignity of every person, regardless of race, color, gender, ethnic or social origin, religion, language, nationality, age, sexual orientation, disability or any other characteristics.

Key words: human trafficking, human rights violations, sexual exploitation, criminal law, crime, human rights 